\title{
LA AFRICANIZACIÓN DE ANTÍGONA (GUINEA ECUATORIAL, 1991) POR TRINIDAD MORGADES BESARI Y SU HORIZONTE DE EXPECTATIVAS: UNA COMPARACIÓN CON ANTÍGONA, FURIOSA (ARGENTINA, 1988) DE GRISELDA GAMBARO
}

\author{
POR \\ MARÍA ZALDUONDO \\ Bluefield College \\ Texas Christian University
}

El personaje de Antígona es un tropo que ha sido retomado por various autores latinoamericanos. ${ }^{1}$ Entre las escritoras que utilizan esta figura emblemática del mundo clásico para denunciar las injusticias en sus respectivos países se encuentran la española María Zambrano con La Tumba de Antígona (1967), la argentina Griselda Gambaro con Antígona furiosa (1985-86) y la ecuatoguineana Trinidad Morgades Besari con Antígona (1991). ${ }^{2}$ De las tres, Morgades transgrede las normas asociadas con el texto trágico antiguo para ofrecernos un tipo de tragicomedia con un final celebratorio cuyo efecto es crear unas expectativas de posible triunfo ante el despotismo. La versión de Morgades se vale de nuestra experiencia como lectores con la tragedia para situarnos en los temas que tradicionalmente la acompañan: el despotismo, la resistencia, la ley divina ante la ley humana, etc., para luego transformar el texto y su representación en una expectativa hacia el cambio social. O sea la dramaturga se vale del "espacio de experiencia" que nos reconecta con la tragedia de antaño tras la figura emblemática de Antígona y la historia reciente de Guinea Ecuatorial (Macías) en el presente para crear un "horizonte de expectativas" de futuro posible que se afirma en la tranformación de un final trágico a uno feliz.

Reinhart Koselleck en sus estudios teóricos sobre la representación de la historia propone una semántica de tiempo histórico através de dos categorias históricas: "espacio

1 Destacados ejemplos de la apropriación moderna de la figura de Antígona se encuentran en autores como Antígona del catalán Salvador Espriu (1950), Antigona Vélez del argentino Leopoldo Marechal (1965) y La pasión según Antigona Pérez del puertorriqueño Luís Rafael Sánchez (1968). La más reciente contribución es Antígona, linaje de hembras (2002) de Jorge Huerta.

2 La obra no muy conocida o estudiada de Zambrano intenta encapsular el gobierno represivo franquista en España. El contexto que abarca Griselda Gambaro se enfrenta a los militares durante la llamada Guerra Sucia (1976-83) y sus operaciones clandestinas para oprimir las voces de oposición en la década de los ochenta. 
de experiencia"y "horizonte de expectativas". Según el historiador alemán "la experiencia es el pasado presente, cuyos eventos han sido incorporados y pueden ser recordados. Dentro de la experiencia una reformulación racional es incluida, al igual que modos de conducta inconsciente que no tienen que estar presente en la consciencia" (272). ${ }^{3}$ Cuando Koselleck se refiere a un "horizonte de expectativas" declara que la expectativa es "el futuro hecho presente; se dirige a lo no-todavía, a lo no vivido, a lo que está por revelarse. La esperanza y el temor, ilusiones y deseos...; todos entran en esta idea de expectativa y lo constituye" (272). ${ }^{4}$ El horizonte sirve como palabra adecuada para articular lo inesperado porque "(el) horizonte es esa línea detrás la cual un nuevo espacio de experiencia se abrirá, pero no se puede ver todavía" (273). ${ }^{5}$ Estos términos "espacio de experiencia" y "horizonte de expectativas" servirán para mostrar cómo la obra de Morgades hace una propuesta radical al cambiar el esperado final trágico de Antígona a un final esperanzante. Parte de la estrategia de horizontes de expectativas que crea la autora se ancla en la africanización del texto griego antiguo. Esta africanización no sólo incluye la historia política guineoecuatoriana recreada y algunas señas culturales (el baile y la danza) sino que incorpora la representación de deidades africanas regionales como Ogun.

En este ensayo se examina la utilización de la tragedia en dos autoras: Trinidad Morgades y Griselda Gambaro. Me interesa contextualizar el momento sociohistórico de estas obras a través de una examinación de la africanización de la tragedia convertida en tragicomedia en el contexto ecuatoguineano y la incorporación del concepto de la predestinación en la obra trágica de Gambaro. En el caso ecuatoguineano me interesa explorar el uso de Ogun como mecanismo teatral y sobrenatural en el drama y de esa manera hacer conexiones con las propensidades feministas que satura la obra de Morgades. Ogun, dios de cambio, representado en la obra como un volcán, destruye el viejo sistema despótico del Presidente pero también inicia la transformación del texto de tragedia a tragicomedia (en el sentido clásico de las obras españolas del siglo de oro). ${ }^{6}$ En realidad este gesto romántico por parte de la autora no sólo subvierte el paradigma

Cita original: "[E]xperience is present past, whose events have been incorporated and can be remembered, Within experience a rational reworking is included, together with unconscious modes of conduct which do not have to be present in awareness" (272).

4 Cita original: "[I]t is future made present; it directs itself to the not-yet, to the nonexperienced, to that which is to be revealed. Hope and fear, wishes and desire..: all enter inot expectation and constitute it " (272).

5 Cita original: The horizon is that line behind which a new space of experience will open, but which cannot yet be seen" (273).

6 Eate final corresponde a las comedias de siglo de oro español donde al final los amantes, antes separados por circumstancias que deban superar, se unen en matrimonio y todo es felicidad y harmonía. La obra de Morgades, de un contexto sumamente trágico y serio es transformado, al final, en un gesto utópico.

Revista Iberoamericana, Vol. LXXX, Núms. 248-249, Julio-Diciembre 2014, 935-949 ISSN 0034-9631 (Impreso)

ISSN 2154-4794 (Electrónico) 
genérico que le proporciona legitimidad catártica a la protagonista, si no que crea una semántica contestataria a nuestras expectativas de Antígona como personaje trágico para ofrecernos una transformación de fracaso esperado/destinado a triunfo deseado/posible.

El drama de Trinidad Morgades Antígona aparece por primera vez en la inauguración de la revista Africa 2000, de 1991. Escrito por una africana y en español, la obra de Morgades apropia un tropo de la antiguedad que todavía clama e insiste en su relevancia en el siglo veintiuno. La escritora ecuatoguineana es actualmente vice presidente de la Universidad de Guinea Ecuatorial. Es una principiante ante la escritura y su única contribución literaria (hasta ahora) parece ser la obra teatral que ocupa el tema de este estudio. En un pequeño ensayo que escribió para El Patio en 1992 la dramaturga explica que su afán para escribir viene de tener un compromiso con la juventud. Ella vincula ese compromiso a la situación política en África. La conexión es breve y ligera pero se entiende que a la autora le preocupan los ideales de la democracia que la obra de Sofócles invita a refexionar: "vi que la situación que planteaba Sofócles en su época encajaba con las realidades sociopolíticas en África. Sofócles vive en la Atenas del S. $\mathrm{V}$. [sic] antes de Cristo en que se intenta ir haciendo avanzar los ideales democráticos, después de las caídas de las tiranías" (Patio 23). Con esta declaración Morgades se une a otros escritores latinoamericanos cuya preocupación es la democracia y sus opuestos, el despotismo y opresión.

En la reciente publicación de Marvin Lewis titulada An Introduction to the Literature of Equatorial Guinea (2007), el escritor exiliado Donato Ndongo Bidyogo comenta y lamenta la mediocridad del teatro en su país y menciona a la Antígona de Morgades y El hombre y la costumbre (1990) de Pancracio Esono Mitogo (1947-) como dos ejemplos de obras de excelente calidad (Lewis 83). Esta breve obra teatral de Morgades que sólo tiene cuatro páginas, es descrita como "una transposición actual, en clave guineana, y con una estructura más simple, de la tragedia homónima de Sófocles" (Ndongo Bidongo 131). ${ }^{7}$ Tres actos respectivamente representan las tres etapas en el desarollo históricopolítico de Guinea Ecuatorial: los albores de la independencia, las elecciones y el desmoronamiento del régimen sanguíneo de Francisco Macías (Rizo). El país fue colonia de España desde las últimas décadas del siglo diecinueve hasta 1968 cuando el General Franco, bajo presión internacional y las Naciones Unidas, fascilitó la descolonización organizando elecciones presidenciales por primera vez en la historia del país.

Los resultados de las elecciones demócratas de 1968 revelaron a Francisco Macías como triunfador. Muy poco después de subir al poder Macías decidió declararse

\footnotetext{
7 La versión original publicada en Africa 2000 es de cuatro páginas pero otra versión publicada en Arizona Journal of Hispanic Cultural Studies 8 (2004) es de seis páginas. Las citas a la obra en este artículo se refieren a la versión original. Cuando Ndongo describe a la obra como "más simple" me imagino que se refiere al reducido número de personajes y la exclusión de hilos dramáticos como las interacciones entre Antígona y su hermana, Ismena u otras relaciones que vemos en la versión de Sófocles.
}

Revista Iberoamericana, Vol. LXXX, Núms. 248-249, Julio-Diciembre 2014, 935-949 
presidente vitalicio iniciando así una dictadura que en 1979 se dio fin con un golpe de estado orquestrado por su sobrino, Teodoro Obiang. El irónicamente llamado "golpe de libertad" engendró una dictadura que ha durado treinta años. Compañíias norteamericanas de petroleo comenzaron a explotar el mineral en las costas de Guinea Ecuatorial en 1996, de esta manera consolidando el poder y control de Obiang sobre la población a través de la corrupción y presión política. En las últimas décadas el país se ha convertido en el tercer exportador mayor de petroleo en la África subsaharina. Se han hecho mejorías en la construcción de carreteras y un aeropuerto internacional pero la mayoría de la población no ha disfrutado de la riqueza que el petroleo ha traido a la élite política del país. Morgades publica su Antígona en 1991 justo antes del desarollo económico desequilibrado auspiciado por las compañías petroleras.

La Antígona de Morgades comienza con movimiento y canto. Las "Voces" cantan, proveen información y una dimensión psicológica a la presentación de los otros personajes, especialmente al "Presidente". Otros personajes incluyen el Pueblo, y tres Soldados y Hombres. Antígona es joven y el guión explica que el personaje "se regocija y se deleita en el baile. En ella todo es alegría de vida. En la penumbra baila un hombre" (28). Las "Voces" que asimilan el coro griego, anuncian su belleza y vitalidad pero presagean "Antígona, eres libertad, vas a morir" (28). Esta declaración de la predestinación del personaje al sacrificio hace que se resigne a su situación y así lo demuestran las acotaciones "Antígona baila la danza de la melancolía, del dolor, de la resignación. Está decidida a llevar a cabo lo que se ha propuesto" (28). Similar a la versión clásica a lo largo de la obra Antígona se enfrenta al poder, aquí representado por el "Presidente" en vez de "Creonte" y desafía su directiva de no enterrar a los muertos. En esta versión el personaje de Polinices, hermano de la Antígona original, es substituido por los difuntos en necesidad de sepultura.

Hay sólo tres actos sin cambio de escenas. En la versión publicada por Africa 2000 a veces las acotaciones, al leerse, no se pueden distinguir del diálogo, Las acotaciones no aparecen en letra cursiva y en paréntasis como ocurre en otras partes del texto. Sabemos que éstas también son acotaciones porque la letra es más pequeña que las utilizadas en el diálogo. Este punto es importante aclarar porque en la primera presentación de las Voces hay acotaciones en letra cursiva y otras que siguen en letra pequeña (no cursiva) donde se presentan a los personajes silenciosos de: "Ley Divina y la Ley Humana, el Poder, el Amor, la Sociedad, el Deber, su conciencia, la Libertad" (28). Estos personajes ocupan espacio en el escenario pero no tienen voz, sirven de recordatorios visuales a estos conceptos claves en la tragedia que nos ocupa. Pero en esta representación hay poco contacto con la homónima de Sófocles. No se hace referencia a Polinices, el hermano de la Antígona antigua y al cual ella insiste en enterrar, o a Hemon (hijo de Creonte), el prometido que no llega a desposar. Sólo se preserva el ideal de resistencia ante la injusticia y el respeto a la ley divina que se encarna en la figura de Antígona.

Revista Iberoamericana, Vol. LXXX, Núms. 248-249, Julio-Diciembre 2014, 935-949 ISSN 0034-9631 (Impreso) 
Entre las ideas que se destacan de la obra de Morgades está aquella del pueblo que se une a la labor de Antígona. En el último y tercer acto cuando tres soldados traen a Antígona frente al Presidente ellos declaran:

Soldado 1: Ha enterrado a los muertos.

Soldado 2: Todo el pueblo siguió su ejemplo.

Soldado 3: Ella es la culpable, por eso la hemos traído. (30)

Pero esta Antígona confía en haber obrado bien ante la ley divina y se muestra "serena, decidida" ante la indignación del Presidente:

Antígona: (Muy serena, decidida) Sólo es justo obedecer las leyes que son dictadas para educar al pueblo, para el bien del pueblo. (30)

Cuando el Presidente se queja de que han intentado matarlo, Antígona lo corrige y revela cómo la paranoia lo ha convertido en un asesino:

Antígona: Sólo tres han atentado contra tu vida; tres no hacen un pueblo. Has mandado a la muerte a ancianos, a mujeres encintas, a jóvenes y niños. Has cambiado presidente, hueles a muerte, a odio, a sangre de inocentes. (31)

Antígona al final se muestra desafiante ante el poder:

Antígona: Prefiero morir con el deber cumplido que vivir haciéndote honores, sabiendo que no los mereces. Prefiero la libertad que me dicta mi conciencia... Prefiero la justicia de Dios que la débil justicia que tú crees que haces. (31)

Lleno de furor el Presidente se lanza a matarla pero ocurre una intervención sobrenatural que las Voces describen ser la erupción de un volcán específico pero sin nombre que destruye al Presidente:

Voces (gritos): ¡El volcán! ¡El volcán! Se ha enfadado el volcán! (31)

Ese "enfado" es la antropomorficación de una erupción volcánica, un tipo de infierno, que da final al déspota.

Presidente: ¡A mí mis fieles! Me quemo, ardo. Más me duele mi espíritu que mis carnes. Socorredme!... ¡No veo! (31)

Es una escena que para estudiosos de la literatura española del siglo de oro pueda recordar "El Burlador de Sevilla y convidado de piedra" de Tirso de Molina (1561?-1648).

Revista Iberoamericana, Vol. LXXX, Núms. 248-249, Julio-Diciembre 2014, $935-949$ 
Quien podría olvidar el fuego inesperado y repentino que aparece al final del Burlador y las palabras de Don Juan: “iQue me quemo! ¡Que me abraso! ¡Muerto soy!” Pero en la obra de Tirso de Molina el protagonista es un burlador de las leyes divinas de honor y muere conforme el imaginario religioso de su tiempo. Ambos déspotas son sujetos al castigo divino y al fuego purificante. La retribución divina alcanza al Presidente en la obra de Morgades, este es el cambio radical que la autora trae a la tragedia de Antígona. Las acotaciones explica lo que el público ha de inferir: el desafío a una estructura de poder y el triunfo de esa resistencia. Este gesto "romántico" de Morgades es lo que contribuye al efecto de esperanza en el horizonte de expectativas que crea un optimismo ante el futuro. Morgades rompe los esquemas que han atrapado a la figura de Antígona a su tragedia y la libera de su tiránico destino. Ante el pesimismo de otras obras que reconstruyen la tragedia de Antígona y la perpetúan, Morgades se atreve a imaginar una sociedad democrática, ideal y justa.

Al final se destruye todo con el fuego y "todo es ceniza" (31) para luego introducir la institución de una nueva ley, la "ley natural" y un nuevo pueblo. En las acotaciones se revela que Antígona ha sobrevivido la catástrofe y un hombre (quien, si recordamos, la acompañó al comienzo) vestido de blanco al igual que Antígona, baila.

(Un nuevo pueblo compuesto de gente joven baila de júbilo, todos vestidos de blanco. Los tambores cantan la victoria con alegría y esperanza. Entre ellos están Antígona y su compañero). (31)

Las acotaciones que aparecen antes del TELON al final declaran:

(Tambores, júbilo, alegría, victoria) (31)

A primera vista, pues, el drama de Morgades parece concentrarse en criticar y comentar sobre el gobierno despótico de Macías ya que también fue destruido, no por un volcán, sino por un golpe de estado. Muchos en el público re-viviendo la "experiencia del espacio" histórico de Guinea Ecuatorial entenderían que las referencias a las atrocidades cometidas por el "Presidente" en la obra coinciden con los del Macías histórico. Se podría extender esta metonimía y asociar el final celebratorio en la obra de Morgades a un intento por parte de la autora de posicionar al gobierno de Obiang como una respuesta positiva ante la dictadura de Macías. Esta observación puede explicar por qué la autora no haya sido blanco de censura, aunque parezca que la representación de la obra lo haya sido. ${ }^{8}$ Sin embargo, lo que queremos proponer es que el efecto de este final feliz

8 Comentando sobre el tema central en su obra teatral la dramaturga señala que "el punto central de mi Antígona es la decision que hay que tomar entre ambas leyes: la Ley Divina y la Ley Humana". Sin

Revista Iberoamericana, Vol. LXXX, Núms. 248-249, Julio-Diciembre 2014, 935-949 ISSN 0034-9631 (Impreso)

ISSN 2154-4794 (Electrónico) 
es la creación de un "horizonte de expectativa" que sobrepasa la realidad histórica del triunfo de Obiang para sugerir otra sociedad futura democrática y libre (que sigue la ley divina, representada en el contexto moderno por las referencias bíblicas).

Por otra parte, la obra teatral de Morgades parece acatar con el ideal de "africanización" que el gobierno de Obiang promovía en los asuntos culturales de la nación de la década de los ochenta. Parte de esta africanización incluía una búsqueda de la "verdadera identidad cultural de la República de Guinea Ecuatorial" después de una "fallida Primera Conferencia Internacional de Cultura Africana-Hispana" de 1984 (Rizo). ${ }^{9}$ En este congreso varios académicos europeos, africanos y americanos participaron bajo la vigilancia de un gobierno interesado en controlar el discurso intelectual y cultural en el país. El "fallo" del congreso, desde la perspectiva del gobierno, ocurrió al no acoplarse a las iniciativas culturales dirigidas por el mismo. Parte de esa iniciativa incluía una reconexión con una visión panafricana de la herencia cultural de Guinea Ecuatorial.

Por esta razón es importante tomar en cuenta la significación histórica y politica del uso del neologismo "africanización” en el contexto cultural de Guinea Ecuatorial. El escritor exiliado Donato Ndongo-Bidyogo es particularmente sensible a la palabra y su uso por el presente gobierno dictatorial que ejerece control social sobre la población:

embargo, la autora no elabora, continuando con "me gustaría haber hecho un gran espectáculo musical a base de tambores" (Patio 24). Menciona que la versión escrita, "produjo su impacto en la gente joven como lo prueba la crítica sana y transparente del joven Siale y Tamara en la revisa El Patio n.12 enero '92" (24). En este comentario la autora se queja de que su obra no fue adecuadamente representada porque los actores fallaron en su interpretacón de las cualidades trágicas en la obra: "a Antígona... le faltó demostrar el momento trágico en que estaba dispuesta a aceptar la muerte a cambio de honrar lo que ella creía que era la ley;... El presidente (Creonte) no hizo que viviéramos el espanto que producen estos presidentes crueles y sanguinarios que una vez instalados se embriagan de poder hasta tal punto que sacrifican la felicidad del pueblo a su propio interés y buscan en sí mismos la razón de su domino y así se convierten en títeres en la mano del mal uso del poder" (Patio 24). Desde el primer parágrafo de "La puesta en escena de Antígona", Morgades revela que la obra participó en un concurso evaluado por un panel de jueces que la dramaturga identifica en el ensayo como "el Jurado", con jota mayúscula. Ella revela que el panel se rehusó a reconocer la obra "ante el mutismo del Jurado a la hora de dar premios y honores" y luego observa que "[E]l jurado no tuvo ojos, ni oídos para captar nada que no fuera descalabro de voces, gestos y empujones que hicieran reir al público juvenil y alborotado. Ni siquiera dió [sic] una mención a la obra de Antígona por haber participado". La reacción de los jueces puede haber sido por la fallida producción pero es posible que tenga que ver con la crítica abierta que se le hace al gobierno de Macías, y que ésta crítica fácilmente se le puede transplantar al régimen de Obiang. Aunque antes en el artículo Morgades sólo hace mención a Franco y Macías, se pueden estblecer vinculaciones con el gobierno de Obiang dado el contexto actual.

9 Para un artículo informativo sobre la construcción de "lo africano" por el régimen de Obiang vea Elisa Rizo, "Discursive Formation of "African Tradition" en Equatorial Guinea's Official Nationalism" donde ella examina el drama El hombre y la costumbre (1990), de Pancrasio Esono Mitogo Obono (1947-) y el valor asignado a esta idea de "cultura africana".

Revista Iberoamericana, Vol. LXXX, Núms. 248-249, Julio-Diciembre 2014, $935-949$ ISSN 0034-9631 (Impreso) ISSN 2154-4794 (Electrónico) 
expresarlo con propriedad -de los que gobiernan en Malabo prosigue los pasos trazados por la primera dictadura, al primar sobre todo los aspectos estáticos de las culturas tradicionales en nombre de una "africanización" mal concebida y peor entendida, en detrimento de la libertad de creación. Desde el poder se dictan los temas que deben abordar los escritores, y las multiples formas de censura concebidas por tan fértiles mentes e impuestas al cuerpo social... (132)

Irónicamente aunque el drama de Morgades se pudiera considerar subversivo por su contenido político, su presentación escenográfica se compagina con la visión de Obiang en la celebración de "lo africano". La africanización del texto consolida el espacio de experiencia para el espectador o lector de la obra. Es una de las formas en que el lenguaje visual y el texto se unen par recrear una experiencia vivida común en el pasado y en el presente (con sugerencias para un posible futuro).

Una de las maneras en que la africanización de Antígona ocurre es a través de la incorporación de "voces" en vez del "coro" dominante en la tragedia griega. En el primer acto la protagonista aparece bailando, en lo que es descrito como una danza de soledad. Desde el comienzo de la obra el público es visual y sonoramente expuesto a lo que es una profunda transformación de la experiencia teatral de un drama griego clásico. En este escenario africano se encuentra una mezcla de movimientos, danza y voces que cantan al compás de tambores. Debra Boyd-Buggs escribe sobre el teatro en Niger y enfatiza la importancia de la música en el teatro africano: "Casi sin excepción el teatro africano incorpora dos manifestaciones esenciales: la música y danza para decir canto y coreografía. El canto y baile son menos aportaciones técnicas que rasgos característicos de civilizaciones africanas" (147). ${ }^{10}$

La crítica afroamericana se suma a explicar que aunque las fuentes del teatro moderno africano provienen esencialmente del Occidente: “... desde 1985 ha habido varios intentos de africanizar el teatro contemporaneo para llegar a una forma que es arte puro, un espectáculo que incluye acción dramática pero también música, canto y baile" (150). ${ }^{11}$

En el teatro africano en general esta "africanización" se refiere específicamente a la presencia de música y danza que se intertejen en el texto para incorporar los sonidos y los rítmos de la cultura folclórica local.

Las diferencias que acomodan la tragedia griega al contexto ecuatoguineano no son sutiles. A diferencia de la versión original, en la Antígona de Morgades el acto heróico

10 Cita original: "Almost without exception African theater incorporates two essential manifestations: music and dance to say song and choreography. Song and dance are less technical than they are character traits of African civilizations" (147).

11 Cita original: “... since 1985 there have been several attempts to Africanize contemporary performance theater in order to arrive at a form that is pure art, a spectacle that includes dramatic action but also music, song and dance" (150). Véase Boyd-Buggs 143-153.

Revista Iberoamericana, Vol. LXXX, Núms. 248-249, Julio-Diciembre 2014, 935-949 ISSN 0034-9631 (Impreso) ISSN 2154-4794 (Electrónico) 
y la actitud rebelde de la protagonista es premiada. En esta reformulación, Creonte es El Presidente, (es decir, Macías), Tebes es Guinea Ecuatorial y Antígona representa la resistencia colectiva cuya victoria sobre la represión señalará un nuevo orden y una nueva nación, aquí la Nueva Jerusalén. En esta versión la protagonista no muere virgen, ya que un compañero, el Hemon africano, la acompaña al final en una celebración matrimonial. Esta pareja representa la Nueva Eva y el Nuevo Adán de la Nueva Jerusalén. ${ }^{12}$ La joven predestinada a la muerte (en el contexto griego) por enterrar a su hermano Polinicio, triunfa, vive y ama. Esta Antígona ni tiene que sacrificar su cuerpo, dando así un ejemplo del "último" sacrificio ante la tiranía, ni sufre las consecuencias de su precursora.

Esta Antígona también entierra los cuerpos de los asesinados por el Presidente. Éste a su vez es destruido por una erupción volcánica, un evento catastrófico, que Lewis describe como la intervención de un deus ex machina que restaura el orden (95). Esta yuxtaposición del caos seguido por el orden y la presencia de un volcán inspira a Rizo a sugerir que el volcán representa el dios africano, Ogum u Ogun. Aunque la crítica no elabora sobre esta imagen referencial, la asociación está conforme a la cosmovisión africana. Su identificación de la presencia de Ogun a través de la imagen del volcán es mordaz porque no sólo hace referencia a la "esfera transicional"y "el principio destructivo/ inventivo de Ogum" sino que abre la puerta a la re-evaluación de las corrientes híbridas que históricamente han colapsado cosmologías griegas y africanas a través de los años. ${ }^{13}$

A consecuencia de estas concatenaciones no es ninguna coincidencia que el dios Ogun, generalmente interpretado como el dios de guerra, es tranculturado y encuentra sus paralelos en los dioses griegos de Hefastos (Volcán-el dios romano de artesanías, metalurgia y fuego) y Aries, el dios de guerra (el dios romano, Marte). Quisiéramos sugerir que la obra dramática de Morgades se presta a una interconexión con el mibili o lo que Rizo define como una "práctica espiritista extendida por la región ecuatorial de Africa y caracterizada por la juxtaposición de iconografías euro-cristianas y africanas" (289). Estas figuras precristianas entran a formar parte de la conciencia colectiva a través de la constante migración extra-territorial entre las naciones que comparten el Golfo de Guinea. ${ }^{14}$ Viajeros, migrantes y comerciantes en la región facilitaron la transmisión de estas creencias. Sanda T. Barnes hace referencia a la interacción cercana que hubo entre los reinos Edo, Fon y Yoruba por siglos y cómo estos sistemas de gobiernos compartieron

12 La intervención final de las Voces es en realidad una referencia bíblica que se encuentra en el libro de Apocalipsis 21:1. En el verso siguiente leemos (Ap. 21:2): "Y vi una ciudad sagrada, la Nueva Jerusalén, viniendo desde el cielo de Dios, preparada como una novia ataviada para su esposo".

13 Por ejemplo, Epido, otra tragedia de Sófocles ha sido representada y transadaptada en Egipto en los setentas por el intelectual y escritor Tawfiq al Hakim (Oedipus Rex 1977) y la obra teatral A Taste of Aloes por la escritora egipcia Nehad Selaiha ha sido descrita como una "Antígona Egipta"

14 También hay que recordar los contactos transatlánticos entre África y el Caribe. Bien se sabe que a Fernando Poo (una de las islas ecuatoguineanas) llegaron trabajadores cubanos en el siglo XIX.

Revista Iberoamericana, Vol. LXXX, Núms. 248-249, Julio-Diciembre 2014, 935-949 ISSN 0034-9631 (Impreso) ISSN 2154-4794 (Electrónico) 
un sistema simbólico que incorporaba los tres elementos de hierro, guerra y la constitución del estado (39). En su referencia a las condiciones culturales que influyen el trato de la mujer en la sociedad ecuatoguineana, por ejemplo, García Romeu comenta que es una sociedad "semi nómada en la que domina la figura del guerrero y del cazador" (56).

La figura de Ogun, asociada con los herreros, guerreros y cazadores se transporta a través del golfo por sus devotos migrantes a otras regiones cercanas. Como bien lo demuestran Barnes en su estudio sobre Ogun, "el alto nivel de movilidad en la región de la Costa Guineana sin duda facilitó el compartir de sistemas de creencias y la ideología de Ogun no fue una excepción" (51). ${ }^{15}$ Esta situación hizo de Ogun un concepto transadaptable porque "los significados atribuidos a Ogun eran abstracciones que no eran vinculados a un contexto cultural singular" (59). ${ }^{16}$

Este reconocimiento de la figura de Ogun como una abstracción migratoria y la observación de Rizo que el territorio ecuatoguineano es un "palimpsesto cultural" (Rizo 290) donde no sólo se depositaron culturas europeas sino también sistemas de creencias africanas que se entremezclan, me permite reestructurar la figura de Antígona como una reformulación de Oya (Oiá, Iansã, Iansan), la diosa del río Niger. Si en las culturas Fang, Bubi, Annobonese y Ndowe no parece haber una versión autóctona, esta se exporta desde el otro lado del golfo guineano desde el cercano y antiguo Reino de Oyo.

En la tradición Yoruba, Oyá es la esposa favorita de Changó y asociada con otro dios, Ogun. Oyá se manifiesta como cambio drástico y repentino, una tempestad o la muerte. De máximo interés para nuestra lectura feminista es esta idea de Oyá y una descripción de ella como la que "se pone los pantalones para guerrear" y "la que crece una barba para guerrear" (Gleason) porque son ambos comportamientos "genderbending" o género-transgresivo y su valentía lo que se resalta en el contexto griego y africano. En su capítulo titulado, "Sacrificial Virgins: Antigone as Moral Agent", Helene P. Foley esclarece algunos de los aspectos sociopolíticos de la percepción del comportamiento de Antígona como género-transgresivo (o que transgrede las normas de su género sexual/biológico):

El que Antígona adopte metas que normalmente sean apropiadas para los hombres, como la búsqueda del honor por el actuar, sería desde esta perspectiva entendido como parte de una situación especial que anima a la hija a tomar acción a favor de los intereses de la familia en ausencia de un pariente masculino dispuesto a hacerlo -aún hasta el punto de [ella aceptar] una muerte suicida heróica. (180; aclaración mía $)^{17}$

15 Cita original "the high level of mobility in the Guinean Coast region no doubt facilitated the sharing of belief systems, and the ideology of Ogun was no exception" (51).

16 Cita original: "the meanings attached to Ogun were abstractions that were not tied to a single cultural context” (59).

17 Cita original: "Antigone's adoption of goals that would normally be appropriate to men, such as the pursuit of honor for her action, would from this perspective be understood as part of a special situation

Revista Iberoamericana, Vol. LXXX, Núms. 248-249, Julio-Diciembre 2014, 935-949 ISSN 0034-9631 (Impreso)

ISSN 2154-4794 (Electrónico) 
Foley observa que en la Antígona de Sofócles el castigo severo de muerte apedreada es justificado porque Antígona ha elegido actuar como un hombre en busca de honor en beneficio de su familia (180).

La valentía de esta Antígona ecuatoguineana y su percebida transgresión son significativas cuando consideramos que ella representa un alejamiento a la situación lúgrube actual de las jóvenes ecuatoguineanas. En una colección de ensayos titulada Visceras, Juan Tomás Avila Laurel asevera que la educación de las jóvenes es tan inadecuada que ellas tienen poca esperanza de alcanzar ser nada más que cosmetólogas, meseras o trabajadoras sexuales. Cuando la Antígona de Morgades hace confrontar la ley divina a la ley humana para así enfrentarse a la tiranía, ella modela una actitud de esperanza y promesa, ya que en su versión las mujeres que actúan bajo una toma de conciencia civil no mueren sino que triunfan, florecen y alcanzan la felicidad matrimonial (conclusión negada a la figura de la versión clásica). Este pastiche de estrategias e imágenes, donde la resolución del conflicto se desarolla en un final feliz celebrado con una ceremonia nupcial y el uso del volcán como mecanismo dramático para eliminar a un tirano, convierte al texto en una elaboración postmoderna que une la tradición con la modernidad.

El mensaje de sacrificio que prevalece en la Antígona de Sófocles no existe en la obra de Morgades. Al destruir Morgades un elemento importante que hace de Antígona una figura trágica, lo que logra es rescatar a Antígona de su predestinación como mártir. Nuestra dramaturga no acepta que Antígona deba sacrificarse y que entregue su cuerpo virginal a la tumba. El cuerpo de esta Antígona se rebela pero también goza en un gesto de optimismo inusitado. En la Antígona furiosa de Gambaro éste no es el caso y la representación de la protagonista se asimila a la de su precursora.

La dramaturga Griselda Gambaro estrena su obra teatral Antígona furiosa por primera vez en 1988 al prinicipio del periodo de democráticazión en Argentina. Hija de inmigrantes italianos, Gambaro nació en Buenos Aires en 1928. Comenzó su carrera de escritora primero como novelista y tuvo que exiliarse desde 1977 a 1980 a causa de la represión política en su país. Uno de sus libros cayó bajo la lista de prohibición en Argentina, motivando el exilio de la autora. Antígona furiosa se escribe entre 1985 y 1986, durante y un poco después de los tribunales que intentaron acusar a los militares responsables por la Guerra Sucia (1976-83) (Feitlowitz 1). El pesimismo, la violencia y la ironía que se encuentra en Antígona furiosa origina en esta profunda relación que el pueblo argentino ha sufrido con gobiernos militares represivos. En una colección de las obras teatrales de Gambaro la compiladora y traductora Marguerite Feitlowitz asevera que "[1]a mayor preocupación de Gambaro siempre ha sido la violencia- sus

that encourages the daughter to act in the interests of her family in the absence of a male relative who is willing to do so-even to the point of a seemingly suicidal heroic death" (180).

Revista Iberoamericana, Vol. LXXX, Núms. 248-249, Julio-Diciembre 2014, 935-949 ISSN 0034-9631 (Impreso) ISSN 2154-4794 (Electrónico) 
raíces, manifestaciones y esferas de influencia, igual que las maneras en que la violencia puede ser percibida, enmascarada y negada" (2). ${ }^{18}$ Con esta obra Gambaro evoca el tema de los desaparecidos durante la Guerra Sucia.

El público que asiste a esta versión de Antígona notará influencias de Bertolt Brecht y otros dramaturgos en su utilización de la violencia. En la primera escena, por ejemplo, encontramos a la protagonista ya horcada que lentamente se incorpora y empieza a cantar su lamento fúnebre. Las acotaciones que describen esta escena nos ayuda a visualizar e imaginar el efecto creado por esta suspensión de realidad. Gambaro nos recuerda el destino que debe cumplir la protagonista, de esta forma convirtiendo en tolerable lo intolerable (Chanter 83). ${ }^{19}$ La economía de la muerte de Antígona cobra sentido en un contexto moderno porque algunos de los temas retratados: la resistencia hacia la autoridad despótica, la ley divina ante la ley humana, todavía son vigentes tras los siglos. ${ }^{20}$

En esta versión latinoamericana los personajes se reunen en un café de Buenos Aires. Creonte es representado como una carcasa en el escenario y dos hombres, Corifeo y Antínoo, se reúnen para comentar las hazañas de la joven Antígona. Corifeo a veces toma el papel de Creonte cuando se introduce en la carcasa. No existe un coro y los tres personajes sirven para re-contar las acciones asociadas con la trama original. Antígona sufre y reclama por su hermano Polinices, menciona a su hermana Ismene y la acusa de tener miedo y no ayudarla (203). Pero esta Antígona también reconoce su deber hacia el pueblo cuando dice: “Antígona: ¡Cadáveres! ¡Cadáveres! ¡Piso muertos! Me rodean los muertos! Me acarician...me abrazan... Me piden.... ¿Qué?” (200).

Ella desea enterrar a los desaparecidos, a los cadáveres sin nombre que el régimen militar niega existen. Esta Antígona (según McNerney en griego su nombre significa "opuesto") se suicida furiosamente al final, cumpliendo la predestinación sofocleana. La gloria se encuentra en el sacrificio y ser mártir. El personaje del contexto argentino asume una postura femenina conforme a las expectativas de las anciedades de su género:

Lejos de la fuerza casi sobrehumana de la heroína clásica, esta Antígona se reconoce y asume en su fragilidad. Admite el miedo que le inspira Creonte y la muerte, el dolor de su matrimonio frustrado con Hemón, de no tener hijos, no envejecer naturalmente, hasta el punto que debe llamarse violentamente al orden, recuperar el orgullo que corresponde a la naturaleza de su personaje. (König 34)

18 Cita original: "Gambaro's chief concern has always been violence - its roots, manifestations, and spheres of influence, as well as the ways in which it may be perceived, masked, and denied" (2).

19 Tina Chanter aquí dialoga con el texto de Sarah Kofman "L'espace de la cesure." Critique 379 (Deciembre 1978): 1143-50. En su artículo Kofman comenta una representación de Antígona que se hizo en Alemania en 1978.

20 Uso la palabra "economía" en el sentido de cómo la muerte de Antígona y su pathos se sujeta a un comercio textual que se intercambia, cobra y compra (inter)textualmente.

Revista Iberoamericana, Vol. LXXX, Núms. 248-249, Julio-Diciembre 2014, 935-949 ISSN 0034-9631 (Impreso)

ISSN 2154-4794 (Electrónico) 
El personaje creado por Gambaro refleja la realidad argentina pero también reproduce algunas de las expectativas sobre la mujer y el sufrimiento, el sacrificio y la vulnerabilidad. Gambaro sujeta a su personaje a la predestinación y tragedia que hace de la muerte de Antígona un espectáculo para consumir y digerir de tal manera que "todo sufrir y negatividad es aguantable, donde aún la muerte se convierte en tolerable" (Chanter 81). ${ }^{21}$ Y así asistimos a la obra de Gambaro con el mismo pesimismo de siempre a través de una identificación con la Antígona sacrificada y derrotada.

Con su Antígona, Morgades subvierte esas expectativas a la misma vez que se une a la corriente de literatura de protesta latinoamericana.

\section{CONCLUSIÓN}

La Antigona furiosa de Morgades es un símbolo de justicia y voluntad humana pero a diferencia de la tragedia griega original, este personaje no muere obviando la voluntad al sacrificio tan crucial en el gesto catártico y redentivo que convierte a Antígona en una heroína trágica. En esta versión Morgades desafía a los ciudadanos a actuar. El texto es un gesto femenista contestatario que logra agenciar a la mujer marginada en la sociedad machista que no percibe a la mujer como agente social.

Y aunque en el drama de Morgades también las leyes de tradición se confrontan a las del estado corrupto como en la tragedia clásica de Sófocles, ella transforma el espacio clásico a un mise en scène africano que privilegia la comunidad y la simbología africana. De esta manera, la deidad supernatural del panteón africano es reanimada y tanto Ogun (representado por la erupción volcánica) como Oyá (representada por Antígona) sirven como "clave guineana" (citando a Ndongo Bidyogo) afrocéntricca, que se manifiestan en clave para la búsqueda de la justicia y la destrucción de la tiranía en Guinea Ecuatorial.

El que Morgades haya escogido un personaje femenino considerado heroico es significativo dada la marginalización de la mujer en la sociedad tradicional africana. Vinculo esta obra a las de los autores mencionados para hacer hincapié en las semejanzas entre autores hispanistas que han tenido que enfrentarse a un legado colonial español y que particularmente escogen la tragedia para reformular su actitud de resistencia ante la tiranía. El contexto africano, con sus sistemas de creencias basados en la naturaleza, crean otros sistemas de significación cuyo resultado es la transformación de la tragedia sofocleana a una obra que nos recuerda los finales de las comedias lopescas. Consecuentemente, al comparar la obra de Morgades con la de Gambaro y el contexto argentino de la década de los ochentas, podemos apreciar las diferencias en la transformación del personaje de Antígona en los dos contextos. Lo radical de Morgades Besari resta en que se atreve a

${ }_{21}$ Cita original: "all suffering and negativity is made bearable, where even death becomes tolerable...." (81).

Revista Iberoamericana, Vol. LXXX, Núms. 248-249, Julio-Diciembre 2014, $935-949$ ISSN 0034-9631 (Impreso)

ISSN 2154-4794 (Electrónico) 
imaginar el triunfo del pueblo ante la tiranía y crea expectativas para un nuevo futuro. Obviando y cuestionando el pesimismo de la predestinación asociada con la Antígona de Sófocles, Morgades celebra una Guinea Ecuatorial posible.

\section{BiBLIOGRAFÍA}

Ávila Laurel, Juan Tomás. Guinea Ecuatorial. Vísceras. Valencia: Imprenta Romeu, 2006. Barnes, Sandra T. y Paula Girshick BenAmos. “Ogún the Empire Builder.” Africa’s Ogún: Old World and New. Sandra T. Burnes, ed. Bloomington: Indiana UP, 1989. 39-64. Boyd-Buggs, Debra. "Aids and Social Intervention Theatre in Niger." Camel Tracks: Critical Perspectives on Sahalian Literature. Trenton, NJ: Africa World P, 2003. 143-53.

Chanter, Tina. "Tragic Dislocations: Antigone's Modern Theatrics." differences: A Journal of Feminist Cultural Studies 10/1 (1998): 75-97.

Cróquer Pedrón, Eleonora. El gesto de Antígona o la escritura como responsabilidad (Clarice Lispector, Diamela Eltity Carmen Boullosa). Santiago de Chile: Editorial Cuarto Propio, 2000.

Feitlowitz, Marguerite. "Crisis, Terror, Disappearance." (Introducción). Information for Foreigners. Three Plays by Griselda Gambaro. Feitlowitz, ed. Evanston, IL: Northwestern, UP. 1992. 1-11.

Foley, Helene P. "Sacrificial Virgins: Antigone as Moral Agent." Female Acts in Greek Tragedy. Princeton, NJ: Princeton UP, 2001.172-200.

Gambaro, Griselda. Antígona furiosa. Teatro 3. Buenos Aires: Ediciones de la Flor, 1989. García Romeu, José. "Mujer y literature en Guinea Ecuatorial.” Imágenes de mujeres. Images de femmes. Benard Fouques y Antonio Martínez González, ed. Caen, España: Universidad de Caen, 1998. 55-63.

Gleason, Judith. OYA. San Francisco: Harper P, 1992.

Lewis, Marvin. An Introduction to the Literature of Equatorial Guinea: Between Colonialism and Dictatorship. Columbia: U of Missouri P, 2007.

Houtzager, Guus. "Niobe." The Complete Encyclopedia of Greek Mythology. NJ: Chartwell Books, 2003. 175-76.

Huerta, Jorge. AntígonaS, linaje de hembras (teatro). Argentina: Editorial Biblo, 2002. König, Irmtrud. "Parodia y transculturación en Antígona furiosa de Griselda Gambaro". Revista Chilena de Literatura 61 (Nov. 2002): 5-20.

Koselleck, Reinhart. Futures Past: On the Semantics of Historical Time. Keith Tribe, trad. Cambridge: Massachusetts Institute of Technology P, 1985.

Marechal, Leopoldo. Antígona Vélez. Buenos Aires: Ediciones Citerea, 1965.

McNerney, Kathleen. "A Guinean Antigone." Arizona Journal of Hispanic Cultural Stuides 8 (2004): 235-38.

Revista Iberoamericana, Vol. LXXX, Núms. 248-249, Julio-Diciembre 2014, $935-949$ ISSN 0034-9631 (Impreso) 
Morgades Besari, Trinidad. Antígona. Africa 20006.4 (1991): 28-31.

"La puesta en escena de Antígona". El Patio 15 (1992): 23-24.

Ndongo Bidyogo, Donato. "Literatura moderna hispanófona en Guinea Ecuatorial". Marta Sofía López, ed. I Jornadas de Estudios Africanos. León: U de León, 2001. 125-35. Ngom Faye, Mbare. Diálogos con Guinea. Panorama de la literatura guineoecuatoriana de expresión castellana a través de sus protagonistas. Madrid: Ediciones Labrys 54, 1996.

"Teatro y escritura femenina en Guinea Ecuatorial: entrevista a Trinidad Morgades Besari." Afro-Hispanic Review (Spring 2000): 104-105.

Rizo, Elisa. "Teatro guineoecuatoriano contemporáneo: el mibili en 'El fracaso de las sombras". Journal of Spanish Cultural Studies 7/3 (2006): 289-310.

"Bridging Literary Traditions in the Hispanic World: Equatorial Guinean Drama the Dictatorial Cultural-Political Order." Critical Perspectives on Afro-Latin American Literature. Antonio Tillis, ed. London: Routledge, 2011. 142-61.

Roberts, Adam. The Wonga Coup: Guns, Thugs, and a Ruthless Determination to Create Mayhem in an Oil-rich Corner of Africa. New York: Public Affairs, 2006.

Sánchez, Luis Rafael. La pasión según Antígona Pérez. Puerto Rico: Ediciones Lugar, 1968.

Steiner, Georg. Antígonas. Barcelona: Editorial Gedisa, 1987. 
